\title{
Management of Indoor Airborne Aspergillus flavus by Traditional Air Purifiers Commonly used in India
}

\author{
Shubhransu Nayak ${ }^{1 *}$ (D), Urmila Dhua², Soma Samanta² ${ }^{(D)}$ and Apurba Chhotaray \\ ${ }^{1}$ Odisha Biodiversity Board, Regional Plant Resource Centre Campus, Nayapalli, Bhubaneswar, Odisha, India. \\ ${ }^{2}$ Crop Protection Division, ICAR-National (Central) Rice Research Institute, Cuttack - 753 006, India.
}

\begin{abstract}
The presence of the ubiquitous fungus Aspergillus flavus along with other seed borne fungi associated with rice in indoor air of farmers' house has been a major health concern. The problem further worsens when the Aspergillus flavus strain has the ability of producing aflatoxins (a group of mycotoxin) and sclerotia (a resistive structure). Diseases and allergic reactions like asthma, rhinitis, allergic broncho pulmonary mycoses, and hypersensitivity pneumonitis may be caused to inhabitants when aflatoxins, spores, vegetative cells and fungal metabolites are inhaled. Therefore, management of this fungus in indoor air of farmers' house is very much essential. Farmers house in Odisha particularly in coastal regions are very much susceptible to fungal infection. Due to poor financial conditions management by sophisticated methods seems difficult. Hence, in the current study, efficiency of some herbal and traditional air purifiers like camphor, dasang jhuna, hawan samagri, cow dung-urine has been evaluated for the suppression of Aspergillus flavus. These materials are known to be used in various rituals and festivals by people in rural areas. All the traditional air purifiers have been found useful to inhibit the growth and proliferation of the fungus particularly cowdung-urine mixure proved to have fungicidal effect. Based on the strong belief and practice of Indian traditions and rituals along with scientific support from the current study and knowledge from literatures, these traditional materials may be very useful for the management and suppression of toxigenic and sclerotic Aspergillus flavus consequently suppressing indoor air problems in farmers' house.
\end{abstract}

Keywords: Aspegillus flavus, aflatoxin, indoor air, traditional air purifier, cowdung urine

\footnotetext{
*Correspondence: shubhransu.crri@gmail.com

(Received: August 08, 2019; accepted: March 20, 2020)

Citation: Nayak S, Dhua U, Samanta S, Chhotaray A. Management of Indoor Airborne Aspergillus flavus by Traditional Air Purifiers Commonly used in India. J Pure Appl Microbiol. 2020;14(2):1577-1588. doi: 10.22207/JPAM.14.2.56

(C) The Author(s) 2020. Open Access. This article is distributed under the terms of the Creative Commons Attribution 4.0 International License which permits unrestricted use, sharing, distribution, and reproduction in any medium, provided you give appropriate credit to the original author(s) and the source, provide a link to the Creative Commons license, and indicate if changes were made.
} 


\section{INTRODUCTION}

The information on airborne allergenic fungal flora in rural agricultural areas is largely lacking still few reports are available describing the presence of allergenic Aspergillus flavus in indoor air of many areas of India which includes farmers' house ${ }^{1 a, 1 b}$. Presence of airborne aflatoxin in the respirable dust samples and the occupational health problem of rice grain handlers of India related to inhalation of aflatoxin and Aspergillus flavus has been already inferred ${ }^{2}$. Fungi are common in indoor and outdoor environment. Numerous studies have shown that exposure to fungi may be associated with acute toxic effects, allergies, and asthma. Researchers believe that More than 80 genera of fungi are associated with symptoms of respiratory tract allergies that is why nearly $10 \%$ of people worldwide have fungal allergy ${ }^{3,4}$. The filamentous fungi Aspergillus flavus is mainly responsible for the production of aflatoxin and also the causal organism for many human allergic reactions like asthma, rhinitis, allergic broncho pulmonary mycoses, and hypersensitivity pneumonitis. These diseases can result from exposure to spores, vegetative cells and fungal metabolites ${ }^{5,6}$. Aflatoxins are a group of mycotoxins and among them aflatoxin B1 is responsible for causing cancer and other chronic diseases of kidney, liver in humans and these are classified as group IA carcinogen by International Agency for Research on Cancer (IARC). This ubiquitous fungus also produces resistant structures known as sclerotia which are often associated with aflatoxin production ${ }^{7,8,9}$.

Most of the farmer population of India and especially in the state of Odisha lives in rural areas with poor financial conditions. They live in huts where the roofs and the walls are made up of rice straw and clay respectively. Due to lack of separate storage facility, the farmers usually keep harvested paddy and other agricultural materials inside their house. The stored paddy grains of farmers often contain a wide diversity of fungi (including both toxigenic and non-toxigenic Aspergillus flavus) which may cause health hazards to the inhabitants ${ }^{10}$. Availability of high humidity and moisture during rainy seasons always keeps up a chance for the proliferation and subsequent toxin production by $A$. flavus and other seed borne fungi. Due to poor financial conditions of the farmers, management of this fungus using sophisticated techniques seems to be very difficult. Hence the use of low cost and easily available home sanitary materials needs to be explored for the management of Aspergillus flavus present in the indoor air of farmers' house.

The beneficial health effects like antifungal, antibacterial properties of some traditional, herbal and low cost air purifiers, like camphor, dasang jhuna, hawan samagri, cow dung-urine have been discussed in various literatures ${ }^{11,12,13,14,15,16,17,18,19,20,21}$. These materials are generally used by the rural population of India in various rituals, festivals and also to maintain sanitation in their house. However, studies regarding the usefulness of these low cost household materials to control airborne toxigenic A. flavus are lacking. Hence, in the current investigation an effort was attempted to explore the effectiveness of these traditional house hold air purifiers against an indoor $A$. flavus strain which was isolated from storage area of farmers' house and which had both aflatoxin and sclerotia producing ability in culture media.

\section{METHODOLOGY \\ Collection of traditional air purifiers}

Common traditional household air purifiers such as Camphor, Dasang jhuna and Havan Samagri were collected from pooja samagri shops i.e. shops which sell materials required for rituals. Cowdung-cowurine mixture was collected from cowshed of National Rice Research Institute, Cuttack, India. A "Commercial air freshener" was also collected from general store and used kept for comparison with traditional materials.

\section{Collection of $A$. flavus strain}

Aspergillus flavus strain A28 was isolated from the indoor air of a farmer in Balasore district of Odisha by passive air sampling method to isolate the fungus, Potato Dextrose Agar (PDA) plates were exposed for one minute inside the house of farmers where harvested paddy was also stored by them. The exposed plates were incubated at $28^{\circ} \mathrm{C}$ where $A$. flavus colonies appeared after few days. The colonies were isolated and screened for the production of aflatoxins and sclerotia. The $A$. flavus strain A28 was selected for the current study as it 
produced higher quantity of aflatoxins as well as sclerotia.

\section{Study of inhibition of $A$. flavus}

As the aim of the current investigation was to study the effectiveness of the above mentioned materials in indoor environment, the inhibition of A. flavus A28 was carried out inside desiccators which were kept air tight to avoid contamination from external environment. One packet of Commercial air freshener, $20 \mathrm{~g}$ of Camphor, $100 \mathrm{ml}$ of fresh Cowdung-cowurine mixture, were kept in separate desiccators. The lids were closed and sealed with petroleum jelly to get the internal environment saturated with these materials. Another two desiccators containing Dasang Jhuna and Hawan Samagri were saturated daily by burning 4g Dasang Jhuna and 2g Hawan Samagri, making smoke and then immediate sealing. This type of experimental design was attempted to make a simulation of what the rural farmers do in their house traditionally. The $A$. flavus strain A28 was inoculated in the centre of PDA plates and then kept in separate desiccators containing the above air purifying environments which were incubated under ambient temperature. A28 was kept inside one desiccators having no air purifier which was used as untreated control. Observations were taken for periodic vegetative growth in terms of colony diameter, changes in colony as well as morphological and microscopic features. After fifteen days of incubation all the culture plates kept in air purifying environments as well as untreated environment were taken out from desiccators and kept at $28^{\circ} \mathrm{C}$ inside incubator for fifteen more days. Observations were then taken for further growth, sporulation, colony, morphological and microscopical changes.

Observation of colony and microscopic characteristics

Color of colony and colony background was recorded using RHS color chart (Royal Horticultural Society, London). Development of sclerotia was observed visually. Microscopic features were observed with the help of inverted microscope (Radical inverted tissue culture microscope). Length of conidiophores stalk and head was observed under $10 \mathrm{X}$ objective $15 \mathrm{X}$ eyepiece and size of conidia was observed under $40 \mathrm{X}$ objective and $15 \mathrm{X}$ eye piece.

\section{Effect of cowdung-urine mixture on sclerotia}

Sclerotia (100no.) of $A$. flavus isolate A28 was put in $25 \mu$ l of sterilized water inside cavity slides which were then kept inside separate humid chambers. The chambers were humidified with $20 \%, 40 \%, 60 \%$ and $100 \%$ of cowdung-urine mixture. Germination of sclerotia and formation of germ tubes were observed after 24 hours under $4 \mathrm{X}$ objective and $15 \mathrm{X}$ eyepiece of microscope. The germination pattern was scored visually with a scale of 1 to 5 where 1-No Growth, 2-Poor growth, 3-Moderate growth, 4-Good growth and 5 -Very Good growth. The average mode of every observation was taken into consideration.

\section{RESULTS}

The impact of common traditional household air purifiers on growth and culture characters of aflatoxigenic, sclerotia producing Aspergillus flavus isolate A28 was studied. The source, composition and traditional use of thee materials are described in Table 1. It was interesting to note the changes in culture colour of A. flavus after exposure to air purifiers. Untreated A28 (control) was showing yellow green colour (R.H.S. No. 146A) as that of a typical A. flavus colony ${ }^{22}$ (www.aspergillusflavus.org) where as the culture colours of A28 plates exposed to Camphor and cowdung-cow urine mixture were yellow white in colour (R.H.S. No. 158). A28 culture turned to greyed orange colour after exposure to Hawan samagri smoke (Table 2; Figure 1).

Exposing A28 to different air purifiers significantly affected the radial growth. About $70 \%$ reduction in colony diameter of A28 was observed after exposure to environment containing camphor where as $90 \%$ inhibition by cowdung-cow urine, $23 \%$ inhibition by hawan samagri and $37 \%$ inhibition by dasang jhuna were observed after 11 days of inoculation (Table 3). The growth of A28 kept in environment containing commercial air freshener was completely inhibited where no mycelia growth was observed. The radial growth of A28 culture which was kept in environment containing cowdung-cow urine further remained constant at $14 \mathrm{~mm}$ after $3^{\text {rd }}$ day of growth.

The culture plates of A28 which were kept inside desiccators for fifteen days containing different air purifiers were taken out and then 


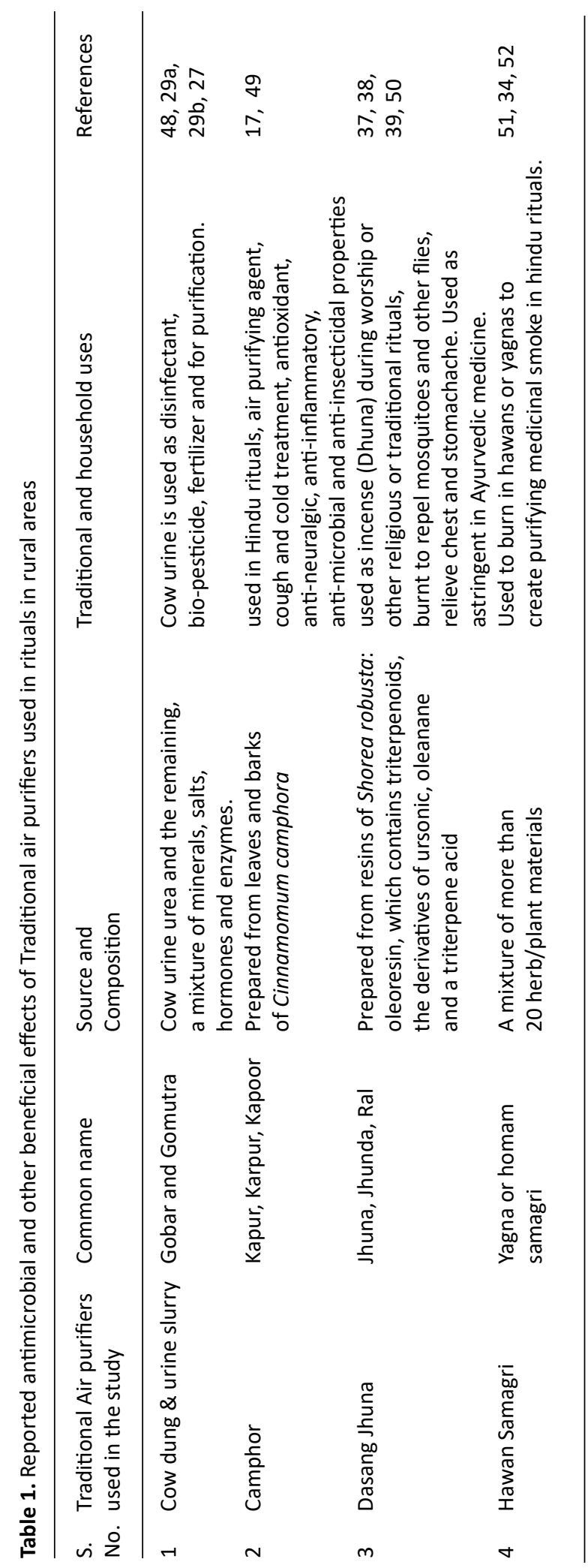

Journal of Pure and Applied Microbiology 
Table 2. Effect of different air purifiers on Growth and culture characters of Aflatoxigenic-sclerotic Aspergillus flavus isolate A28

\begin{tabular}{lccc}
\hline Treatment & $\begin{array}{l}* \text { Culture colour } \\
\text { Media surface }\end{array}$ & $\begin{array}{c}\text { (periphery } \rightarrow \text { Centre) } \\
\text { Plate bottom }\end{array}$ & $\begin{array}{c}\text { Colony diameter } \\
\text { on day 11 }\end{array}$ \\
\hline Control & $146 \mathrm{~A}, 16 \mathrm{~A}$ & $164 \mathrm{~A}, 162 \mathrm{~B}$ & 90 \\
Camphor & $158 \mathrm{~B}$ & $199 \mathrm{~B}$ & 27.25 \\
Commercial air freshener & - & - & 0 \\
Cow-dung + Cow urine & $158 \mathrm{~B}, 165 \mathrm{~A}$ & $161 \mathrm{~A}$ & 14 \\
Dasang jhuna & $145 \mathrm{C}, 9 \mathrm{C}$ & $161 \mathrm{C}$ & 57 \\
Hawan samagri & $163 \mathrm{~B}, 199 \mathrm{~A}, 155 \mathrm{~A}$ & $164 \mathrm{~A}, 161 \mathrm{C}$ & 69 \\
\hline
\end{tabular}

*Culture colour = as per RHS colour chart: RHS Nos. 1 to13 Yellow group; 14 to 23 yellow orange group; 144 to 154 is yellow green group;155 white group;158 yellow white group ;160 to 162 greyed yellow;163 to 165 greyed orange group ; 199 Greyed brown . A, B,C,D etc along with RHS no. indicate the various shades of colour

Table 3. Effect of different air purifiers on periodic growth of aflatoxigenic-sclerotic Aspergillus flavus isolate A28 on PDA. Colony diameter in $\mathrm{mm}$

\begin{tabular}{lccccccccccc}
\hline Treatments & day 1 & day 2 & day 3 & day 4 & day 5 & day 6 & day 7 & day 8 & day 9 & day 10 day 11 \\
\hline Untreated Control & 19 & 24 & 36.5 & 46 & 53 & 63 & 73 & 80.5 & 86.5 & 88.5 & 90 \\
Camphor & 12.5 & 15.5 & 18.5 & 19.5 & 22.5 & 23 & 23.5 & 23.5 & 24.5 & 26 & 27.25 \\
Commercial air freshener & 0 & 0 & 0 & 0 & 0 & 0 & 0 & 0 & 0 & 0 & 0 \\
Cowdung+Urine & 11 & 13.5 & 14 & 14 & 14 & 14 & 14 & 14 & 14 & 14 & 14 \\
Dasang jhuna & 0 & 0 & 7.5 & 8.5 & 14 & 19 & 26 & 31 & 39 & 47 & 57 \\
Hawan samagri & 15.5 & 25.5 & 37 & 47 & 50 & 55 & 57.5 & 60.5 & 63.5 & 66.5 & 69 \\
\hline
\end{tabular}

LSD at $\mathrm{P}<0.05$ is $2.31 ; \mathrm{LSD}$ at $\mathrm{P}<0.01$ is 3.05

Table 4. Culture characters of aflatoxigenic-sclerotic $A$. flavus isolate A28 which was first incubated in environment containing different air purifiers and then transferred to normal conditions

\begin{tabular}{lccc}
\hline & \multicolumn{2}{c}{$*$ Culture colour (periphery to Centre) } & \\
Treatment & Media surface & Plate bottom & $\begin{array}{c}\text { Colony } \\
\text { diameter } \\
\text { on day 30 }\end{array}$ \\
\hline Camphor & $199 \mathrm{~A}, 155 \mathrm{~A}$ & 70 \\
Commercial air freshener & $146 \mathrm{~A}, 15 \mathrm{~A}$ & $165 \mathrm{C}$ & 60 \\
Cow-dung + Cow urine & $161 \mathrm{C}$ & $161 \mathrm{~B}, 166 \mathrm{~A}$ & 14 \\
$\begin{array}{l}\text { Dasang jhuna } \\
\text { Hawan samagri }\end{array}$ & $144 \mathrm{D}, 9 \mathrm{C}$ & $161 \mathrm{~A}$ & 80 \\
& $164 \mathrm{~A}, 163 \mathrm{~A}, 155 \mathrm{~A}, 164 \mathrm{~B}$ & $164 \mathrm{C}$ & 86 \\
\hline
\end{tabular}

${ }^{*}$ Culture colour = as per RHS colour chart: RHS Nos. 1 to 13 Yellow group; 14 to 23 yellow orange group; 144 to 154 is yellow green group;155 white group;158 yellow white group ;160to 162 greyed yellow ;163 to 165 greyed orange group ;199 Greyed brown . A, B,C,D etc along with RHS no. indicate the various shades of colour

incubated at $28^{\circ} \mathrm{C}$ to observe further changes in growth and culture characteristics. It was very significant to observe that A28 plates which were kept in environment containing commercial air freshener where no growth has been observed earlier, resumed growth very fast after shifting normal growth conditions in incubator (Table 4 and Fig. 2). The radial growth rate in this case was fastest than other purifiers which reached up to $60 \mathrm{~mm}$ within 15 days after shifting to optimum growing conditions. Rates of growth were relatively slower in A28 cultures treated 
with Camphor, Dasang jhuna and Hawan samagri where the radial growth (colony diameter) was $70 \mathrm{~mm} .80 \mathrm{~mm}$ and $86 \mathrm{~mm}$ respectively after 15 days of shifting to optimum growing conditions as compared to $27.25 \mathrm{~mm}, 57 \mathrm{~mm}$ and $69 \mathrm{~mm}$ of growth respectively after 11 days inside air purifier environments (Fig. 2). Culture colours of A28 exposed to Camphor, Cow-dung + Cow urine, Dasang jhuna and Hawan samagri were still different at this stage than the untreated A28. A28 exposed to cowshed type environment i.e. Cow dung + Cow urine did not grow even after transferring to normal growing condition (Table 4). Variations in microscopic characters like length of stalk and size of head of conidiophores were also observed during incubation or exposure to the environment containing air purifiers. Maximum of $83 \%$ reduction in stalk length of conidiophores was observed when A. flavus A28 cultures were treated with 'Cowdung-cow urine' environment. In this case the stalk length was $170.6 \mu \mathrm{m}$ as compared to untreated control where it was $981.3 \mu \mathrm{m}$. Further, reduction in stalk length was also observed in treatments by camphor (64\%), Dasang jhuna (63\%) and Hawan samagri (43\%) where the length of stalk was observed as $350.4 \mu \mathrm{m}, 364 \mu \mathrm{m}$ and $558.3 \mu \mathrm{m}$ respectively (Table 5). Size of head of conidiophores was also found to be affected by various treatments. Maximum of $45 \%$ reduction in head size was observed in conidiophores of $A$. flavus cultures exposed to Cowdung-cow urine where the head size was $19.6 \mu \mathrm{m}$ as compared to $35.9 \mu \mathrm{m}$ in untreated control. Reduction in head size was also observed in cultures treated with Camphor (37\%), Dasang jhuna (40\%) and Hawan samagri (15\%) treatments where the size of the heads were $22.8 \mu \mathrm{m}, 21.7$ $\mu \mathrm{m}$ and $30.4 \mu \mathrm{m}$ respectively.

Table 5. Effect of different air purifiers on morphological/microscopical features of aflatoxigenic-sclerotic A. flavus isolate $\mathrm{A} 28$

\begin{tabular}{|c|c|c|c|c|}
\hline \multirow[t]{2}{*}{$\begin{array}{l}\text { Air } \\
\text { purifiers }\end{array}$} & \multicolumn{2}{|c|}{$\begin{array}{l}\text { A. flavus exposed to } \\
\text { air-purifiers for } 15 \text { days } \\
\text { in desiccators }\end{array}$} & \multicolumn{2}{|c|}{$\begin{array}{l}\text { A. flavus earlier exposed } \\
\text { to air purifiers and then } \\
\text { grown under ambient } \\
\text { condition for } 15 \text { days }\end{array}$} \\
\hline & $\begin{array}{l}\text { Length of } \\
\text { stalk }(\mu \mathrm{m})\end{array}$ & $\begin{array}{c}\text { Size of } \\
\text { head }(\mu \mathrm{m})\end{array}$ & $\begin{array}{l}\text { Length of } \\
\text { stalk }(\mu \mathrm{m})\end{array}$ & $\begin{array}{c}\text { Size of } \\
\text { head }(\mu \mathrm{m})\end{array}$ \\
\hline Control & 981.3 & 35.9 & 982.5 & 36 \\
\hline Camphor & 350.4 & 20.5 & 470.3 & 30 \\
\hline Commercial air freshener & - & - & 654.25 & 36 \\
\hline Cowdung+Urine & 170.6 & 19.6 & 302.5 & 30 \\
\hline Dasang jhuna & 364.0 & 21.7 & 480.5 & 30.4 \\
\hline Hawan samagri & 558.3 & 30.4 & 607.5 & 32.4 \\
\hline
\end{tabular}

Table 6. Germination and growth of $A$. flavus sclerotia in cow urine

\begin{tabular}{cccc}
\hline S. No. $\begin{array}{ccc}\text { Concentration of } \\
\text { cow urine tested }\end{array}$ & $*$ In 1-5 Scale & $*$ In 1-5 & Germination / \\
& & Scale Range \\
& & & $\begin{array}{c}\text { growth in } \geq 90 \% \\
\text { (Average mode) }\end{array}$ \\
& sclerotia
\end{tabular}

\begin{tabular}{lcccc}
\hline 1. & $20 \%$ & 1 & 1 & No Growth \\
2. & $40 \%$ & 1 & 1 & No Growth \\
3. & $60 \%$ & 1 & 1 & No Growth \\
4. & 1 & 1 & No Growth \\
5. & $40 \%$ & 4 & Good growth \\
& Control & 4 & 4 & \\
\hline
\end{tabular}

\footnotetext{
* In 1-5 scale, evaluation of germination/ growth of A. flavus sclerotia
} 


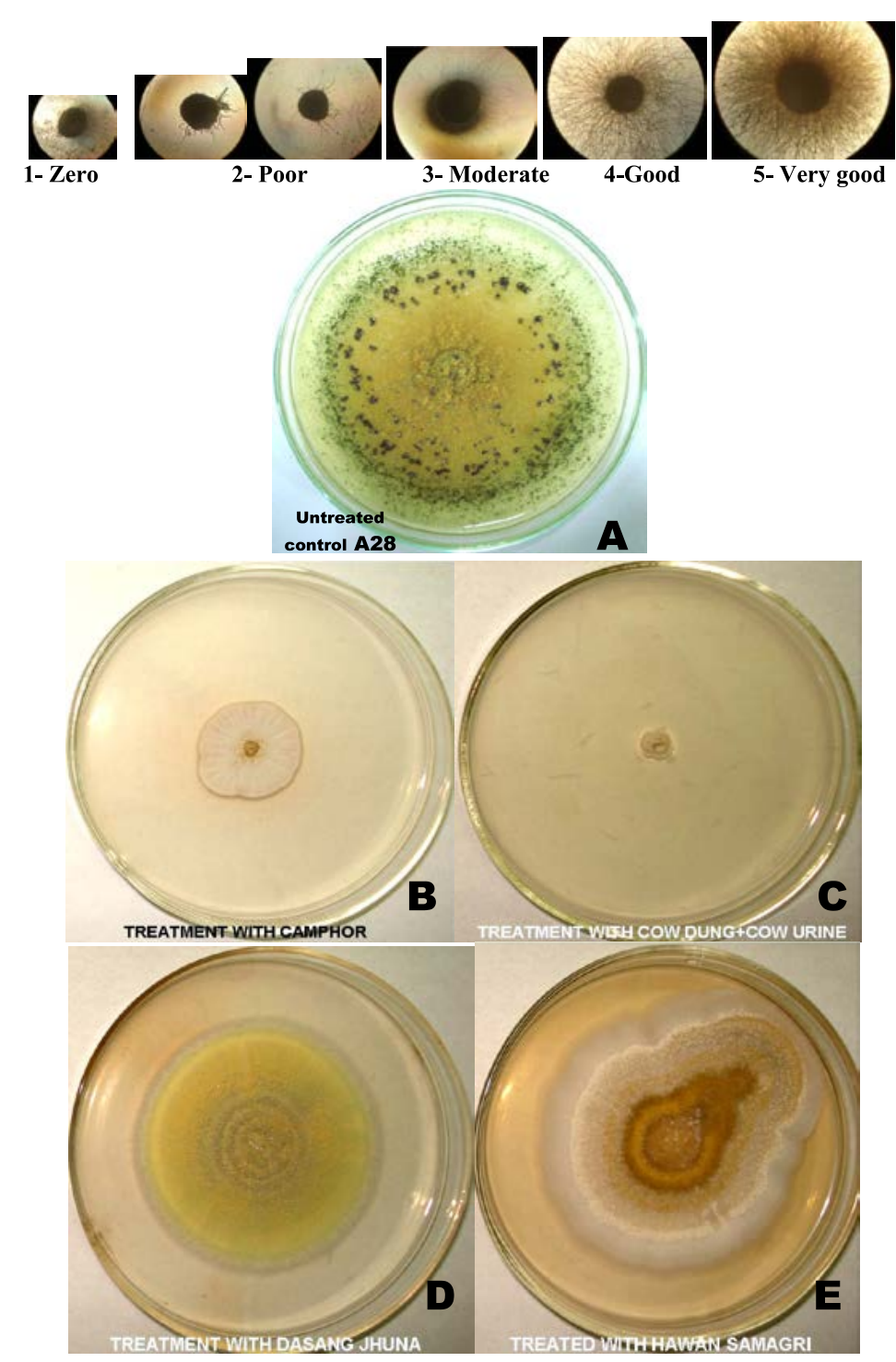

Fig. 1. Effect of different air purifiers on culture characters of aflatoxigenic-sclerotic Aspergillus flavus isolate A28

The changes in microscopic features of A. flavus isolate A28 were observed after shifting the cultures out of desiccators to normal growing conditions. Cultures which were earlier exposed to commercial air freshener resumed growth at a faster rate after shifting to normal growing conditions where the length of stalk was found to be $654.25 \mu \mathrm{m}$ as compared to $982 \mu \mathrm{m}$ in untreated control in 30th day of growth. The stalk lengths in cultures of other treatments were still less than the untreated control where the length of stalks in Cowdung-cow urine, Camphor, Dasang jhuna and Hawan samagri were $302.5 \mu \mathrm{m}, 470.3 \mu \mathrm{m}$,
$480.4 \mu \mathrm{m}$ and $607.5 \mu \mathrm{m}$ respectively (Table 5). Similarly head sizes of conidiophores were still less than the control where it was $30 \mu \mathrm{m}$ in Cowdungcow urine, $30 \mu \mathrm{m}$ in Camphor, $30.4 \mu \mathrm{m}$ Dasang jhuna and $32.4 \mu \mathrm{m}$ in Hawan samagri treatments. Head size in cultures treated with commercial air freshener was at par with untreated control where it was $36 \mu \mathrm{m}$ (Table 5). Though radial growth of A28 exposed to Cow dung-Cow urine environment was not observed after shifting to normal conditions little growth in conidiophores was seen. However, this environment was still very much found to be effective even after shifting to normal condition 
as $69 \%$ reduction in length of conidiophores stalk was recorded.

Formation of sclerotia was inhibited in the $A$. flavus A28 cultures exposed to air purifiers where as dark L-type sclerotia $(>400 \mu \mathrm{m})$ was produced in cultures of untreated control (Fig. 1). The germination of sclerotia was completely inhibited by humidification with all concentrations ( $20 \%$ to $100 \%$ ) cow urine (Table 6 ). In untreated control the average mode and range of mode of germ tube formation was 4 i.e. good germination of sclerotia where as in all treated plates the average mode as well as range of mode was 1 which indicated no germination of sclerotia.

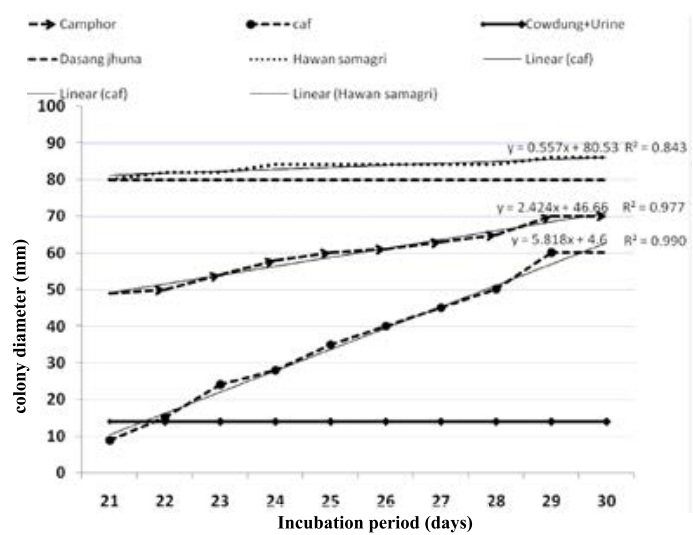

Fig. 2. Growth in colony diameter of aflatoxigenicsclerotic Aspergillus flavus earlier exposed to different air purifiers for 15 days and later on shifted to ambient conditions.

*caf: commercial air freshener

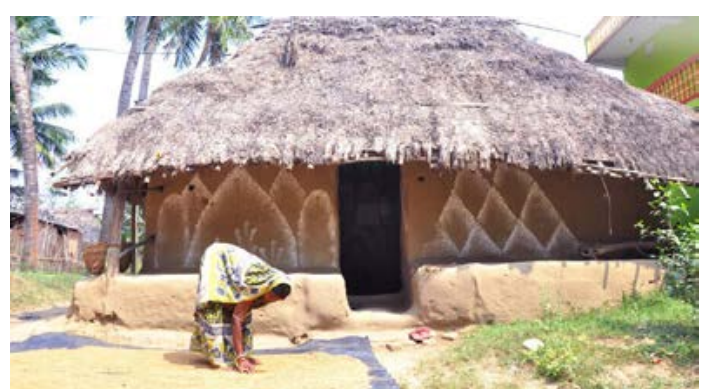

Fig. 3. A typical structure of house built by farmers and other people in rural areas where they stay as well as store their harvested agricultural products. Roof is made up of rice straw and the walls are made up of clay. (Photo source: https://www.mycitylinks.in/why-this-village-inodisha-has-no-doors).

\section{DISCUSSION}

Moulds in indoor environments have been implicated in allergies for many years. Valid concerns exist regarding the relationship between indoor air, mold exposure and human disease ${ }^{23,5,6}$. Hence suitable ways for the management (preferably eco-friendly approaches) of indoor fungi especially fungus like toxigenic $A$. flavus need to be explored. In rural areas of Odisha most of the people live in huts where the roof is made up of rice straw and walls are made up of clay. This type of structure supposed to make a susceptible environment for fungal growth and proliferation. One of such structure is represented in figure 3. Considering the poor financial conditions the management of indoor $A$. flavus through the use of traditional, household and eco-friendly materials becomes more important. Hence, the current study emphasised the usefulness of some of the common household traditional air purifiers like cow dung-urine mixture, camphor, jhuna and hawan samagri for the management of toxigenic and sclerotic indoor Aspergillus flavus fungi. The source, composition and traditional use of these materials are described in Table 1.

Cow urine has been proved to be inhibitory to the mycelial growth and spore germination of pathogens including Aspergillus species as observed in the current investigation ${ }^{16,24}$. Jabin ${ }^{25}$ reported that cow urine has inhibitory activity against Fusarium sp. and cow urine mixed with leaf extracts of Vitex negundo completely inhibited the mycelial growth of the pathogen. Antifungal activity of cow urine distillate against Aspergillus flavus was analysed by Snathasivam et $\mathrm{al}^{12}$ where minimum inhibition zone was $2.3 \mathrm{~mm}$. Sapre and Varma ${ }^{26}$ evaluated cow urine at different concentrations and durations, against the growth of $S$. rolfsii by poisoned food technique and found cow urine reducing mycelial growth, number, size and even viability of sclerotia of soil borne pathogen. Similarly Raja et al. ${ }^{27}$ observed inhibition of mycelial growth, germination and production of sclerotia in $R$. solani after treatment with cow urine and buffalo urine mixture at $5 \%$ concentration. The treated sclerotia even lost viability when reinoculated. Basak and Lee ${ }^{28}$ reported that fresh cow urine and cow dung has positive response in suppression of mycelial growth of many Fusarium species. 
Basak et $a^{29 a, 29 b}$ found cow urine more effective than cow dung in inhibiting mycelial growth and sclerotia germination in Sclerotinia sclerotiorum. Camphor is prepared from the wood extract of Cinnamomum camphora (L.), which have been found to be efficiently suppressing many bacteria and fungi like Candida. Albicans, C. tropicalis, C. glabrata and Aspergillus niger, Aspergillus parasiticus, Fusarium graminearum ${ }^{30,17,31,32}$. A. fumigatus was found to be completely inhibited by oils of camphor up to 72 hours with maximum $0.5 \%$ concentration $^{11}$. Bacteria like $B$. cereus have been inhibited by Camphor oil where an inhibition zone diameter of $45 \mathrm{~mm}$ has been observed ${ }^{33}$. Camphor is used daily in Hindu family to light diyas, by burning camphor as part of daily prayer. It also contributes to purify the surrounding air and prevent harmful bacteria, viruses and mosquitoes away. According to Ayurveda when the camphor is burnt it purifies the atmosphere. When the devotees place their palms on Aarti (a plate in which camphor is burned) and put the palms of their nose and eyes, they absorb the medicinal benefits (http://www.ayurvedicindia.info). In this study reduction in mycelia growth, sporulation and microscopic structures of indoor strains of A. flavus were observed when treated with environment containing camphor.

Havan or homam or agnihotra or yagya is spiritual or religious ceremony generally practiced at temples and homes in Hindu culture where mixtures of herbal and medicinal plant material are sacrificed in fire in a specialised fire pit called yagya kunda. This is believed to be a scientific method where the slow combustion, sublimation and the transformation into vapour phase of the sacrificed materials take place in the yagya fire. The materials which are used to sacrifice in the havan fire are known as Havan Samgri. The thermal energy, the fumes generated by above process and the religious chanting of mantras during havan or yagya leads to a holistic cure of patients even infected with acute diseases like tuberculosis and epilepsy. The burning of these havan samagri has been reported to have many other beneficial health effects including antibacterial and anti fungal properties $\mathrm{s}^{34,35}$ (http:// www.vedicstore.com). Nautiyal et a ${ }^{36}$ represented a comprehensive analysis and scientific validation of our ancient knowledge about the effect of ethnopharmacological aspects of natural products' smoke for therapy and health care on airborne bacterial composition and dynamics. He observed that the load of aerial bacterial pathogens like Corynebacterium urealyticum, Curtobacterium flaccumfaciens, Enterobacter aerogenes (Klebsiella mobilis), Kocuria rosea, Pseudomonas syringae pv. persicae, Staphylococcus lentus, and Xanthomonas campestris pv. tardicrescens etc. could be reduced up to $94 \%$ by the burning of havan samagri smoke in a confined room. The inhibitory effect even persisted for a month duration. In the current study also the fumes produced by regular burning of havan samgri lead to the suppression of growth and development of toxigenic and sclerotic indoor Aspergillus flavus.

Jhuna, Jhunda, Dhuna or Ral is prepared from the resin of Sal tree (Shorea robusta) by making cuts on bark of the tree mostly by tribal people. Traditionally jhuna has been used as incense during worship or other religious or traditional rituals in the tribal and rural areas of Odisha. It is burnt to repel mosquitoes and other flies and a charcoal paste prepared after burning the resin is applied as kajal $^{37}$. It has also carminative, stomachic and astringent properties. It gives relief in skin disorders, pain in nerves, burn injury, fever, enlargement of spleen, abnormal discharge from body (menorrhagia, leucorrhoea), diarrhea, and bleeding piles. It is also given in gonorrhea and for weak digestion. In Siddha, it is suggested for ulcers, wounds and menopausal disorders ${ }^{38,39,40}$. Jhuna has also been reported to have antibacterial property as it suppressed the growth of many bacterial pathogens like Escherichia coli, Salmonella typhi, Pseudomonas $s p$. and Staphylococcus aureus culture ${ }^{41,42}$. In the current study, growth and development of A. flavus could be suppressed by the continuous smoke of jhuna.

Reduction in microscopic structures like length of conidiophores and size of head by the treatment of traditional air purifiers were observed in the present study. Such reduction along with filamentation of fungal cultures has also been found after treatment with other antifungals ${ }^{43}$. Some plant extracts also exerted profound effects on the development of aflatoxigenic fungi, clearly altering their morphology, conidiogenesis and aflatoxin synthesis. 
In the current study all traditional and commercial air purifiers could suppress the formation of sclerotia whereas dark and L-type sclerotia were observed in untreated cultures of $A$. flavus. Sclerotia are pigmented, compacted aggregates of hyphae, which resist unfavorable environmental conditions and capable of remaining dormant for long periods $s^{7,44,8,9}$. They are considered by some researchers to be a vestige of the sexual structures, cleistothecia, which also are woven from specialized hyphae but each contains thousands of ascospores ${ }^{45,46}$. High concentrations of aflatoxins may occur in both conidia and sclerotia of $A$. flavus ${ }^{47}$.

The current investigation clearly depicted the potential of traditional herbal air purifiers which are commonly used in the rural areas of India in the management of indoor $A$. flavus which has produced and aflatoxin as well as sclerotia. India is a very spiritualistic country and especially in rural areas people observe number of festivals. In the state of Odisha particularly in coastal regions where people have a strong faith in God Jagannath and his rituals, a tradition of "Bara masare tera parba" i.e. observation of "Thirteen main festivals in twelve months" prevails besides number of small festivals. In all these traditional activities there is a practice of using materials from herbal and natural origin. The four traditional materials used in the current study i.e cow dung cow urine, camphor, hawan samagri and jhuna have been used by rural people, if not all, in most of their rituals during festivals. Cow dung slurry is coated on the walls regularly before the commencement of many festivals. Even jhuna is smoked daily with coconut bark fibers as a part of evening worship. As discussed above, the antimicrobial and other health benefit effects of these traditional materials were presented in Table 1. As per findings of the current study, it could be understood that the regular use of these materials in households of rural areas might be the reason behind the suppression or elimination of Aspergillus flavus and other indoor fungal microflora. Subsequently that might be the reason of people in these areas are not affected with sick building syndrome even if staying in conditions which are susceptible to fungal infection where as sick building syndrome is quite prevalent in many countries in America and Europe.

\section{CONCLUSION}

All traditional air purifiers used in the study were found to be effective to control the growth and development of Aspergillus flavus. Cow dung and urine mixture found to be the most effective in controlling the vegetative growth and sporulation. The inhibition persisted even after shifting treated cultures to normal conditions. Cow urine in all concentrations of humidification completely suppressed the germination of sclerotia. The commercial air freshener, though completely suppressed the growth of $A$. flavus initially but when placed in ambient conditions it showed aggressive growth. Now a days people are more aware of the harmful effects of many synthetic products which they are being exposed like food materials, pesticides etc. The result of which is that a gradual inclination towards herbal and natural products is being generated among public in general and also herbal product market is growing rapidly. Hence intensive research efforts are very much required to develop novel products from these household traditional air purifiers so that poor rural people and also general public may get more precise benefit out of it. Methods may be devised and formulations may be developed using the traditional household air purifiers for a low cost management of fungal sickness in farmers' house.

\section{ACKNOWLEDGEMENTS}

Authors are grateful to the Director, ICAR-National Rice research Institute, Cuttack (previously Central Rice research Institute) for providing necessary facilities for the study. Authors are also grateful to the Chairman and Member Secretary of Odisha Biodiversity Board, Bhubaneswar.

\section{CONFLICT OF INTEREST} conflict of interest.

The authors declare that there is no

\section{AUTHORS' CONTRIBUTION}

All authors listed have made a substantial, direct and intellectual contribution to the work, and approved it for publication.

\section{FUNDING}

This study was supported by Indian Council of Agricultural Research, New Delhi, India. 


\section{DATA AVAILABILITY}

All datasets generated or analyzed during this study are included in the manuscript.

\section{ETHICS STATEMENT}

This article does not contain any studies with human participants or animals performed by any of the authors.

\section{REFERENCES}

1a. Adhikari A, Sen MM, Gupta-bhattacharya S, Chanda S. Airborne viable, non-viable, and allergenic fungi in a rural agricultural area of India: a 2-year study at five outdoor sampling stations. Sci Total Environ. 2004;326(1-3):123-141. https://doi.org/10.1016/j. scitotenv.2003.12.007

1b. Adhikari A, Sen MM, Gupta-Bhattacharya S, Chanda S. Volumetric assessment of airborne fungi in two sections of a rural indoor dairy cattle shed. Env Int. 2004;29(8):1071-1078. https://doi.org/10.1016/ S0160-4120(03)00103-X

2. Ghosh T, Gangopadhyay S, Das, B. Prevalence of respiratory symptoms and disorders among rice mill workers in India. Environ Health Prev Med. 2014;19(3):226-233. https://doi.org/10.1007/ s12199-014-0384-8

3. Pavan R, Manjunath K. Qualitative analysis of indoor and outdoor airborne fungi in cowshed. J Mycol. 2014. https://doi.org/10.1155/2014/985921

4. Khan $\mathrm{AH}$, Karuppayil SM. Fungal pollution of indoor environments and its management. Saudi J Biol Sci. 2012;19(4):405-26. https://doi.org/10.1016/j. sjbs.2012.06.002

5. Klich MA. Health effects of Aspergillus in food and air. Toxicol Indust Health. 2009;25(9-10):657-67. https:// doi.org/10.1177/0748233709348271

6. Mensah-Attipoe J, Toyinbo O. Fungal Growth and Aerosolization from Various Conditions and Materials. In Fungal Infection. IntechOpen. 2019. https://doi. org/10.5772/intechopen.81565

7. Cotty PJ. Aflatoxin and sclerotial production by Aspergillus flavus: Influence of $\mathrm{pH}$. Phytopathol. 1988;78:1250-1253. https://doi.org/10.1094/ Phyto-78-1250

8. Wicklow DT, Shotwell L. intrafungal distribution of aflatoxins among conidia and sclerotia of Aspergillus flavus and Aspergillus parasiticus. Can J Microbiol. 1983;29:1-5. https://doi.org/10.1139/m83-001

9. Okoth SA, Nyongesa B, Joutsjoki V, Korhonen $\mathrm{H}$, Ayugi V, Kang'ethe, EK. Sclerotia formation and toxin production in large sclerotial Aspergillus flavus isolates from Kenya. Advances in Microbiology. 2016;6(01):47. https://doi.org/10.4236/aim.2016.61005

10. Nayak S, Dhua U, Samanta S. Morphological and toxigenic study of Aspergillus flavus from indoor air. J Environ Biol. 2019;40:648-654. https://doi. org/10.22438/jeb/40/4/MRN-775

11. Khan AAH, Naseem. Plant Volatile Oils as Growth Inhibitors for Aspergillus parasiticus. Int J Curr Res.
2011;3(10):71-74.

12. Sathasivam A, Muthuselvam M, Rajendran R. Antimicrobial Activities of Cow Urine Distillate against Some Clinical Pathogens. Global J Pharmacol. 2010;4(1):41-44.

13. Vijayalakshmi R, Saranya VTK. Effect of "GoMutra" on Plant Growth and its Antifungal and Antibacterial Activity. Herbal Tech Industry. 2010;6(6):06-11.

14. Deshmukh SS, Rajgure SS, Ingole SP. Antifungal activity of cow urine. IOSR J Pharm. 2012;2(5):27-30. https:// doi.org/10.9790/3013-25302730

15. OrissaReview:http://orissa.gov.in/emagazine/ Orissareview/2010/July/engpdf/july\%202010.pdf; 2010. Accessed on $12^{\text {th }}$ August 2019.

16. Patil HSR, Makari HK, Gurumurthy $H$, Ragavendra $H L$, Chetan DM, Kumar HSA. Effect of Cow Urine on Fungal Spore Germination. Trade Sci Inc Biotech. 2007;1(3).

17. Chen W, Vermaak I, Viljoen A. Camphor: A Fumigant during the Black Death and a Coveted Fragrant Wood in Ancient Egypt and Babylon, A Review. Molecules. 2013;18:5434-5454. https://doi.org/10.3390/ molecules 18055434

18. Rangari P. Screening of Antibacterial Sensitivty of essential Oils of Camphor and Cinnamon. Shodh Anusandhan Samachar. 2011;1:22-26.

19. Joseph B, Sankarganesh P. Antifungal Efficacy of Panchagavya. International J Pharm Tech Res. 2011;3(1):585-588.

20. E-Health Portal: http://apollopharmacy.apollolife.com/ Articles/Traditional-HerbalRemedies Naturally\%20 Beautiful.aspx. Accessed on $12^{\text {th }}$ August 2019.

21. Pfeffer G, Behera DK. Contemporary Society: Identity, Intervention and Ideology in Tribal India and Beyond. Volume 7. India: Concept Publishing Company, A/15-16, Commercial Block, Mohan Garden, New Delhi-110059 (2008).

22. Brandt ME, Gade L, McCloskey CB, Balajee SA. A typical Aspergillus flavus Isolates Associated with Chronic Azole Therapy. J Clinic Microbiol. 2009;47(10):33723375. https://doi.org/10.1128/JCM.00671-09

23. Flanning B, Samson, Robert A, Miller, DJ. Microorganisms in home and indoor work environments: Diversity, Health Impacts, Investigation and control, Tayler and Francis. 2001. https://doi. org/10.1201/9780203302934

24. Deshmukh SS, Rajgure SS, Ingole SP. Antifungal activity of cow urine. IOSR J Pharmacy. 2012;2(5):27-30. https://doi.org/10.9790/3013-25302730

25. Ghosh T, Biswas MK. Evaluation of antibacterial and antifungal activity of cow urine against some seed borne microflora. Int J Curr Microbiol Appl Sci. 2018;7(05):1714-1727. https://doi.org/10.20546/ ijcmas.2018.705.201

26. Gotora T, Masaka L, Sungirai M. Effect of cow urine on the growth characteristics of Fusarium lateritium, an important coffee fungus in Zimbabwe. Int J Agron. 2014. https://doi.org/10.1155/2014/986068

27. Hoh JM, Dhanashree B. Antifungal effect of cow's urine distillate on Candida species. J Ayurveda Integrat Medicine. 2017;8(4):233-237. https://doi. 


\section{org/10.1016/j.jaim.2017.04.009}

28. Prakash N, Sinha AP. In vitro studies of inhibitory activity of plant extracts and cow urine on mycelial growth of stem rot, Sclerotim oryzae of rice. J Appl Nat Sci. 2017;9(1):24-8. https://doi.org/10.31018/ jans.v9i1.1142

29. Basak $A B$, Lee MW, Lee TS. In vitro inhibitory activity of cow urine and cow dung of Fusarium solani f. sp. cucurbitae. Mycobiol. 2002;30(1):51-54.

29. Basak AB, Lee MW, Lee TS. Inhibitive activity of cow urine and cow dung against Sclerotinia sclerotiorum of Cucumber. Mycobiol. 2002;30(3):175-9.

30. Abad MJ, Ansuategui M, Bermejo P. Active antifungal substances from natural sources. Arkivoc. 2007;1(7):116-45. https://doi.org/10.3998/ ark.5550190.0008.711

31. Mahilrajan S, Nandakumar J, Kailayalingam R, Manoharan NA, SriVijeindran S. Screening the antifungal activity of essential oils against decay fungi from palmyrah leaf handicrafts. Biol Res. 2014;47(1):35. https://doi.org/10.1186/0717-628747-35

32. Mokbel AA, Alharbi AA. Antifungal effects of basil and camphor essential oils against'Aspergillus flavus' and'A. parasiticus'. Australian J Crop Sci. 2015;9(6):532.

33. Othman $M$, Saada $H$, Matsuda $Y$. Antifungal activity of some plant extracts and essential oils against fungi-infested organic archaeological artefacts. Archaeometry. 2019. https://doi.org/10.1111/ arcm.12500

34. Sharma PK, Ayub S, Tripathi CN, Ajnavi S, Dubey SK. AGNIHOTRA-A Non Conventional Solution to Air Pollution. Int J Innov Res Sci Eng. 2014:1-3.

35. Bansal P, Kaur R, Gupta V, Kumar S, Kaur R. Is there any scientific basis of hawan to be used in epilepsyprevention/cure?.J Epilepsy Res. 2015;5(2):33. https:// doi.org/10.14581/jer.15009

36. Nautiyal CS, Chauhan PS, Nene YL. Medicinal smoke reduces airborne bacteria. J Ethnopharma. 2007;114(3):446-51. https://doi.org/10.1016/j. jep.2007.08.038

37. Singh H, Baske PK, Saravanan R, Dhole P. Traditional uses and marketing of crude oleoresin Jhuna of Shorea robusta Dipterocarpaceae by tribes in Odisha, Envis News Lett. 2015;20(1): https://www.researchgate.net/ publication/302965013.

38. Sharma ME, Kumar AS. Traditional medicinal plants of Rajasthan used in tribal medicine-A review. Int J Life Sci Pharma Res. 2013;3:38-42.
39. Soni RK, Dixit V, Irchhaiya RI, Singh H. A review update on Shorea robusta Gaertn f.(Sal). J Drug Delivery Therapeutics. 2013;3(6):127-32. https://doi. org/10.22270/jddt.v3i6.653

40. Bimbima: https://www.bimbima.com/ayurveda/saltree-shorea-robusta-information-and-uses/49/: Last updated 2017. Accessed on $12^{\text {th }}$ August 2019.

41. Banerjee RP, Banerjee S, Sarkar P, Pradhan NK. Phytochemical analysis and antimicrobial activity of natural resin (lal dhuna) from Shorea robusta (sal), Int J Pharma Sci Health Care. 2014;3(4):52-60.

42. Apollo Pharmacy: http://apollopharmacy.apollolife. com/Articles/Traditional-HerbalRemediesNaturally\%20Beautiful.aspx\#: Accessed on $12^{\text {th }}$ August 2019.

43. Steinbach WJ, Schell WA, Blankenship JR, Onyewu C, Heitman J, Perfect JR. In vitro interactions between antifungals and immunosuppressants against Aspergillus fumigatus. Antimicro Agents Chemotherapy. 2004;48(5):1664-9. https://doi. org/10.1128/AAC.48.5.1664-1669.2004

44. Bayman P, Cotty PJ. Genetic diversity in Aspergillus flavus: association with aflatoxin production and morphology. Can J Bot. 1993;71:23-31. https://doi. org/10.1139/b93-003

45. Geiser DM, Dorner JW, Bruce WH, Taylor JW. The Phylogenetics of Mycotoxin and Sclerotium Production in Aspergillus flavus and Aspergillus oryzae. Fung Genet Biol. 2000;31:169-179.

46. Yager LN. Early developmental events during asexual and sexual sporulation in Aspergillus nidulans. In: Bennett JW, Klich MA. eds. Aspergillus. Biology and Industrial Applications. Boston: ButterworthHeinemann, 1992: 19-41.

47. Wicklow DT, Cole RJ. Tremorgenic indole metabolites and aflatoxins in sclerotia of Aspergillus flavus: An evolutionary perspective. Can J Bot. 1982;60:525-528. https://doi.org/10.1139/b82-070

48. Mohanty I, Senapati MR, Jena D, Palai S. Diversified uses of cow urine. Int J Pharm Pharm Sci. 2014;6(3):20-22.

49. Ayurvedic India: http://www.ayurvedicindia.info/thebenefits-of-camphor-kapurkapoor/: Accessed on $12^{\text {th }}$ August 2019.

50. Hota RK, Bapuji M. Triterpenoids from the resin of Shorea robusta. Phytochem. 1993;32(2):466-468. https://doi.org/10.1016/S0031-9422(00)95019-2

51. Down to earth: http://www.downtoearth.org.in/news/ holy-smoke-disinfects-indoor-air-4043. Accessed on $12^{\text {th }}$ August 2019. 